\title{
Teachers as Zookeepers? How Picture Books Describe Classroom Management
}

\author{
CHRISTINA BELCHER \\ Redeemer University College \\ KIMBERLY MAICH \\ Memorial University \\ MONTE HARDY \\ Brock University
}

\section{Abstract}

Engaging the lens of classroom management, this research explores how teachers have been represented in children's picture books as classroom managers. Picture books from the A-Zoo $7^{\text {th }}$ Edition (2005) serve as a foundational data set to explore how the personification of teachers and the reality of the teaching experience are mirrored over time. Charteris's heuristic of epistemological shudders (2014) - identifying a paradox which opens up possibilities for meaning making — was utilized alongside Krippendorff's (1989) content analysis framework. Findings inform how the representation of teachers has portrayed a postmodern, deconstructive worldview regarding classroom management and professional representation, inviting further study into society's ongoing perceptions of the teacher.

Keywords

picture books, teachers, classroom management, personification

\section{Introduction}

Historically, teachers have been a source of both interest and mystery to society. Examinations of teacher portrayals in literature, including children's literature, reach far back into the history of schooling. The often-heard adage - those who can, do; those who can't, teach - has done little to show either the depth required (or necessity for) effective class management within the art and science of teaching and learning that occurs within classroom settings. It is probable that society takes most of its views of teaching from popular press or mediated observations, where representations of teachers are portrayed as stereotypes, rather than from research journals or professional information. Such representations and their narratives give explicit and implicit messages about teacher appearances, roles, and value, to society (Townsend \& Ryan, 2012).

This paper unfolds a study of children's literature across three cohorts of children's picture books. As popularity for reading to children became advocated as beneficial for later learning by school boards in the 1950s, the popularity and availability of books for children on schooling, its contours, and its key players, increased. The resulting picture books were embedded with the social norms of the era in which they were written. As each 
cohort of picture books is compared across decades, the reader gets a cultural snapshot of how classroom management, gender representation, and the view of the profession of teaching within society has changed over time. Such change also is reflective of the profession of the teacher. This paper will support the view that children's picture books are not innocent and only for the young, but also act as a reflection of what society values about education in the areas of classroom management, gender representations and the view of teaching as a 'lesser' profession.

Data for the cohorts emerge from the 2005 version of the compilation of books on teachers from A to Zoo: Subject Access to Children's Picture Books ( $7^{\text {th }} \mathrm{ed}$.) Since picture books from the earliest cohort (1970s-1980s) were difficult to obtain due to library culls of older material (see sampling units, below) this first cohort is minimal. The second cohort (1990s) has more literature, and this increase continues into the third cohort of books (2000s). Changes in the gender of teachers as authors, changes in their portrayal as teachers regarding classroom management and how society views teachers in the profession inform one another as the study proceeds. This change in perception provides a sharp contrast and groundwork for others who wish to study this topic further. It is the opinion of the authors, that teachers in our current multicultural classrooms could benefit from the information gleaned from this study, especially as it relates to the view of teaching as a profession.

\section{Literature Review}

The depiction of teachers has been - and remains - a common social occurrence in picture books. Teacher portrayals have changed in some ways since the early $20^{\text {th }}$ century, but often teacher dispositions and expectations arise from a public perception or past myth about teaching, reflecting the culture and norms in which the writers of picture books lived.

For example, Christen (2001) examined early images of teachers specifically related to $17^{\text {th }}$ century literature focussing on character education in schools. His work was fueled by Reformation theology, and presented a classical example of absolute teacher authority. Since many schools in the $17^{\text {th }}$ century were founded by Christians, the ideals of mentoring, discipline and respect were prominent. Christen's portrayal concentrated more on pedagogy and classical education as a way of modeling learning. In the $19^{\text {th }}$ century, Cummins (2009) described the honor, influence and education that led to be a teacher, especially for women. Teaching was a choice and an emancipatory act; a career which ended upon marriage. De Witt (2013) analyzed literature from the $20^{\text {th }}$ and $21^{\text {st }}$ centuries, noting how parental roles compared to the call of teaching. It is rare that such analyses are limited to surface-level visual descriptors - though illustrations are meaningful and reflective (Feathers \& Arya, 2012). Rather, teachers were typically examined as embodied reflections of socio-political contexts in varied stereotypical permutations (e.g., hero), stigmatized (e.g., ageism, sexism), binary (e.g., villain/victim) metaphorical (e.g., teacher as saviour) and/or subversive (i.e., threatening change) manners (parenting), with researchers making rich, authentic connections between society, identity, and its schoolbased educators (Cummins, 2009; Hansen, 2009; Hollis-Sawyer \& Cuevas, 2013; Mockler, 2004; Muchmore \& Sayre, 2009).

In 1992, Trousdale found that representations of teachers included metaphors, such as teacher as gatekeeper, and involved physical descriptors including comparison of gender, nameless female representations, issues of power, and race. It is of interest to note that a researcher portrays teachers within the cultural norms of the century is which the 
research is penned, and hence, teacher representation also involves socio-political and current norms. Sandefur and Moore (2004) carried out ethnographic content analysis of 62 titles and 92 images of teachers with a view to the power of stereotypes and clichés, especially negative ones, stating that such representations shape and define the 'idea' of the teacher in the collective consciousness of society. However, in the above representations, being able to manage a classroom is seldom referenced, and if so, not in positive or important light.

A common thread within teacher research in picture books has been that of culture, and how teachers have been portrayed within it and by it. Currently, in the $21^{\text {st }}$ century, there appears to be a shift in tone, character and purpose in teacher portrayal, and in research on teachers in general. Upon reflection, this change informs a more deconstructive and negative lens of the teacher, viewing teaching less as a profession, and more as a performance. In 2009, Muchmore and Sayer examined literary portrayals of teachers as being that of nurturer, subversive, conformist, hero, villain, victim and outsider. Later in 2012, Muchmore classified teacher identities in works of literature over categories of genre, time periods and multiple audiences. His theoretical framework argues that both types of teachers (real and imagined) are similarly storied creations when they are represented through text. Similarities and overlap occur between fictional depiction and authentic depiction. Muchmore's thematic images portray teachers as victims, potential or actual threats to the social fabric, or as inspirational characters. In his 2012 analysis of 44 literary works, Muchmore discovered diverse patterns: teachers being portrayed as eccentrics, nurturers, subversives, conformists, heroes, villains, victims, outsiders, immutable forces, and economic survivors. As victims, they are at the behest of systems, governments, students or unfortunate circumstances. As inspirational characters, teachers are identified as leaders, saviours, and encouragers of excellence/personal best/democratic thinking. These portrayals of teachers/ identities vary, with some being stereotypical of the era in which they were written. For example, early story may have women portrayed as stay-at-home mothers, or caricatured into anthropomorphic stereotypes of the social character presumed as being suited to a teacher. Although these portrayals reflect the social norms in which they were written, they may not fit the reality of the current classroom setting, but rather may mirror reflections that may not currently seem professionally or politically correct.

Phillips and Sturm (2013), in a more professional inquiry of teacher portrayal, "examine[d] the illustrations and the texts of thirteen picture books for young children on the topic of preparing for and starting kindergarten to assess whether, and to what extent, they depict forty-nine criteria for developmentally appropriate kindergarten practice" ( $p$. 469-470). One section reviews teacher-child interactions. Teachers are seen as exhibiting an interactive role with students, such as nurturing, providing activities, interacting in play, greetings, conversations, modelling, etc. Here the professional and relational side of teaching comes to the fore.

Of particular interest to our research paper, Dockett, Perry, and Whitton (2010) utilized content analysis (e.g., culture, appearance, name, gender, etc.) to examine the images of teachers found in 164 picture books (1967-2007), looking at what was depicted, what was not depicted, and what was dominant in such images. Of the 187 images that emerged, the most dominant role (93\%) ascribed to the typically female teachers depicted was that of classroom managers. Classroom managers were defined as those who set up 
and care for the classroom environment, greet others, provide supervision, and give direction; which would also mirror the experience of a friendly school janitor if left to minimum scrutiny, or to a teacher who was not deeply concerned about classroom management, within current culture.

Our research project delves more into the specifics of classroom management by classroom managers/teachers. Our lens in this article is that of how teacher/student relationships engage what the story in the picture book tells us or wants us to believe, implicitly or explicitly, about teaching and learning, and how this unfolds as a perception of the life of the classroom. This perception of life is not always accurate, and this is where key elements are not voiced, but rather are missing in some of the texts; and hence, 'epistemological shudders' frequently arise. A focus on looking for classroom management and how it is given value may differ between seasoned and new teachers, and definitely differs when we take into consideration the era and view of the author as storyteller. It is also noted that most of the portrayals of teachers, despite humor or satire, when considered deeply, are negative ones which portray teaching as less than a valued profession.

\section{Methodology}

This project launches into an examination of cultural impact within education across decades, while also troubling the waters of perception regarding the representation of the profession of teaching, and the depiction of the teacher in early children's literature - when it comes to classroom management. Both manifest and latent data were examined to align with this purpose, using a cohort-by-cohort, socio-political examination within a critical approach: Charteris's heuristic of epistemological shudders (2014) —identifying a paradox which opens up possibilities for meaning making — was utilized as a conceptual framework and heuristic throughout the study; a way of exploring what was not being said in printed text, as well as what may be inferred by certain terms of language alongside Krippendorff's (1989) content analysis framework.

Krippendorf's content analysis model, (1989), involves six steps. Step one is referred to as design and focuses on context. Although this research took place in the early twentyfirst century in a North American academic context, its design is a retrospective examination. From the 1970 s to the 2000 s, teacher portrayal in children's literature was examined specifically in the depiction of teachers as classroom managers. Step two of Krippendorf's framework is delineating the sampling units or unitizing. This research unitized 77 children's pictures books $(N=77)$ from the seventh edition reference book $A$ to Zoo: Subject Access to Children's Picture Books (2005) under subject heading Career: Teacher. The process of sampling is encompassed within step three (Krippendorf). Sample size was limited to 39 of 77 picture books (50.6\%) from 1977-2005, which were obtainable in the public library system in a mid-sized Ontario, Canada city. For the purpose of analysis, these 39 books were divided into cohorts based on decade of publication: cohort one (1970s-1980s; $n=3)$; cohort two (1990s; $n=14)$; and cohort three (2000s; $n=22)$ (refer to Table 1). Krippendorf's step four is coding. In this case, the main teacher (character or depiction) in each picture book was coded within 14 categories: (1) decade

(2) title (3) author (4) perspective (5) personal characteristics (6) depiction (7) subject specificity (8) appearance (8) language (10) approach (11) effectiveness (12) location (13) author perspective (14) and ethics (Dedeoglu et al., 2011, Dyches et al, 2009; Leininger et al, 2010). Step five was the process of drawing inferences. According to Krippendorf 
(1989), this step is of the highest importance. In the case of this analysis, inferences related to historical context, socio-cultural-political temporal change, perceptions of schooling, worldview and power shifts. Step six, validation, emerged akin to the cross-decade analysis of similarities and differences in overall conclusions.

Table 1

Complete Book List

\begin{tabular}{|c|c|c|c|}
\hline Cohort & Publication & Author & Title \\
\hline 1 & 1977 & Allard & Miss Nelson is Missing \\
\hline \multirow[t]{2}{*}{$(n=3)$} & 1982 & Allard & Miss Nelson is Back \\
\hline & 1985 & Munsch & Thomas's Snowsuit \\
\hline 2 & 1990 & Cole & The Magic Schoolbus: Lost in the Solar System \\
\hline \multirow{12}{*}{$(n=14)$} & 1990 & Danneberg & First Day Jitters \\
\hline & 1991 & James & Dear Mr. Blueberry \\
\hline & 1992 & Cole & The Magic Schoolbus: On the Ocean Floor \\
\hline & 1992 & Bunting & Our Teacher's Having a Baby \\
\hline & 1992 & Houston & My Great Aunt Arizona \\
\hline & 1996 & Henkes & Lily's Purple Plastic Purse \\
\hline & 1996 & Cole & The Magic Schoolbus: Inside a Beehive \\
\hline & 1998 & Polacco & Thank you Mr. Falker \\
\hline & 1998 & Calmenson & The Teeny Tiny Teacher \\
\hline & 1998 & Finchler & Miss Malarkey Won't be in Today \\
\hline & 1999 & Priceman & Emeline at the Circus \\
\hline & 1999 & Borden & Good Luck, Mrs. K! \\
\hline & 2000 & Brown & Arthur's Teacher Moves in \\
\hline \multirow{16}{*}{$(n=22)$} & 2000 & Dannenbur & First Year Letter \\
\hline & 2000 & Passen & The Attack of the 50-Foot Teacher \\
\hline & 2000 & Wheatley & Luke's Way of Looking \\
\hline & 2000 & Hallinan & My Teacher's My Friend \\
\hline & 2000 & Finchler & Testing Miss Malarkey \\
\hline & 2001 & Liebman & I want to be a Teacher \\
\hline & 2001 & Parakevas & Gracie Graves and the Kids from Room 402 \\
\hline & 2001 & Pattou & Mrs. Spitzer's Garden \\
\hline & 2001 & Reynolds & The Magnificent Piano Recital \\
\hline & 2001 & Flanagan & Teachers \\
\hline & 2001 & Teyssèdre & Joseph Wants to Read \\
\hline & 2002 & Johnson & Substitute Teacher Plans \\
\hline & 2002 & Passen & The Incredible Shrinking Teacher \\
\hline & 2002 & Wood & What Teachers Can't Do \\
\hline & 2002 & Finchler & You're a Good Sport, Miss Malarkey \\
\hline & 2003 & Garland & Miss Smith's Incredible Story Book \\
\hline
\end{tabular}


As noted earlier, epistemological shudders, as defined by Charteris, acts as a heuristic from which to turn a reflexive gaze on discourse (printed or spoken), stirring up a shudder metaphor of puzzle and/or paradox. It affirms an insight that something is amiss, or not quite complete, provoking the reader to consider what is not being said along with what is being said. In doing so, unquestioned assumptions around content and context are probed, and questions are raised about identity within discourse, creating spaces for seeking truer depth and understanding of any reading or conversation. In short, this process produces "Aha!" moments throughout analysis, engaging a deeply reflective, analytic lens.

\section{Books and Their Analysis}

This study confirms that representations of ethical standards (i.e., care, respect, integrity, trust) are essential in the disposition of a teacher within public representation, but extends to examine how such dispositions relate to the depiction of teachers as classroom managers through children's picture books. The Table 1 sample provides visual and written information of the books explored from a collection. These books were mined to find out what portrayals may reveal about teaching as a career, and how the role of a professional teacher is presented; specifically, when it comes to classroom management. The books in the table were divided into three separate cohorts of teacher representation patterns. Attention was paid to what was stated or included about the reality of the teacher and teaching, and what was omitted in perception of each cohort. Attention was also given to cultural change across each cohort, to understand the impact of education upon culture, or the impact of culture upon education.

\section{Cohort Overviews}

The books in this study were examined by cohort in chart form, with key components of attention emerging on perceptions and representations of teachers, not only in the way teachers were portrayed in terms of classroom management, but how classroom management itself became entwined within illustrated representation, dispositional representation, and representation of power.

Snapshot of Cohort 1 Prior to Analysis. The first cohort of books, (1970s-1980s), $(n=3)$, portrayed female teachers in dresses or skirts; and in one representation, the pseudo-character of a witch. Teachers were characterized as those who managed the classroom by fear or power, and male principals were represented as being helpless within the chaos. Classroom management was authoritarian and stern, suggesting that teaching was a power struggle. Teachers were portrayed as authority figures within the classroom, for good or ill. Satire tended to replace direct authoritarian rule, making class management both extreme and disrespectful. Teaching was primarily seen as women's work. Behaviour was the focus more than intellect or character. There was also an undercurrent that teachers 
were not very bright or competent, and principals were less so-hence, the profession was not promoted in an appealing way. All of the teachers teaching in the primary grades were depicted as female. All of the picture book authors were male.

Snapshot of Cohort 2 Prior to Analysis. The second cohort of books (1990s) included a subset of 14 books $(n=14)$. Contemporary themes such as learning style, science, and social life were increasingly evident, as well as the inclusion of special needs (i.e., dyslexia) in the classroom environment. The view of the student as an individual was becoming prominent. Change in illustrated portrayal also acted as a harbinger of change in teaching style. Males were entering the teaching profession, and were portrayed to be more professional and competent than their stereotypical, caricatured female counterparts in illustration and in tone. Class management was becoming more individualized rather than as a directive to the whole class. Three of the teachers were represented as male and ten as female. Eight of the authors were female, and two were male.

Snapshot of Cohort 3 Prior to Analysis. The third cohort of books, (2000-2005), had the largest representation: 22 picture books $(n=22)$. There was more emphasis on the permissive classroom. Teachers were portrayed as being stereotypical, or as being superheros or heros of 'time gone by'. Emphasis was on having fun, being liked and being fair. Less emphasis was on learning and more was on experiencing. The representation of the teachers in the text were sixteen female, four male, two cartoon depictions and two professional examples which were more geared to being advertising manuals for teaching as a profession. In this selection, thirteen authors were female and nine were male.

One arising epistemological shudder that did not appear to belong in the study was the depicted awareness of cartoon/comic and anthropomorphic characters for the teachers in a number of these books across all cohorts. Such depiction raises the question: What does that infer to the reader about professional ability, teacher expectation or the public view of teaching over time, and the task of teaching?

\section{Discussion of the Cohort-by-Cohort View}

Cohort One (1970s-1980s).

Table 1

Cohort 1: Professional Change, Social Change, \& Possible Significance

\begin{tabular}{|c|c|c|c|}
\hline Character & $\begin{array}{l}\text { Professional change } \\
\text { (Illustration and } \\
\text { valued disposition and } \\
\text { pedagogy) }\end{array}$ & $\begin{array}{l}\text { Social change } \\
\text { (Class management and } \\
\text { teaching focus) }\end{array}$ & $\begin{array}{l}\text { Possible significance } \\
\text { (Representation of } \\
\text { power) }\end{array}$ \\
\hline $\begin{array}{l}\text { Miss Nelson- } \\
1977 \\
\text { (male author) } \\
\text { Miss Nelson } \\
\text { Series: Miss }\end{array}$ & $\begin{array}{l}\text { - Authoritarian vs. } \\
\text { permissive teacher style } \\
\text {-Traditional classroom; } \\
\text { teacher is female, } \\
\text { witch/permissive }\end{array}$ & $\begin{array}{l}\text { - Permissive at start; } \\
\text { authoritarian at end - } \\
\text { scared into behaviour } \\
\text { (which is best) }\end{array}$ & $\begin{array}{l}\text { - Female teachers do not } \\
\text { have the authority unless } \\
\text { they become witches }\end{array}$ \\
\hline
\end{tabular}




\begin{tabular}{|c|c|c|c|}
\hline $\begin{array}{l}\text { Nelson Is } \\
\text { Missing }\end{array}$ & $\begin{array}{l}\text { - Dressed in } \\
\text { skirts/dresses } \\
\text {-Class management is } \\
\text { overt or permissive } \\
\text { - Manipulative style; } \\
\text { authoritarian stance is } \\
\text { favoured }\end{array}$ & $\begin{array}{l}\text { - Stereotypes: } \\
\text { Blonde/Black hair; } \\
\text { Innocence/Evil; alter- } \\
\text { egos } \\
\text {-Power lies in the } \\
\text { classroom authority of } \\
\text { the teacher; repeated line } \\
\text { "something will have to } \\
\text { be done" - said by the } \\
\text { teacher }\end{array}$ & $\begin{array}{l}\text { - Change to see students as } \\
\text { more in need of control } \\
\text { than as learners } \\
\text { - Blonde teacher (nice) is a } \\
\text { stereotype of beauty over } \\
\text { brain; but black-haired } \\
\text { witch means business }\end{array}$ \\
\hline $\begin{array}{l}\text { Miss Nelson- } \\
1982 \text { (male } \\
\text { author), Miss } \\
\text { Nelson Series: } \\
\text { Miss Nelson is } \\
\text { Back }\end{array}$ & $\begin{array}{l}\text { - As above: } \\
\text { authoritarian vs. } \\
\text { permissive teacher style } \\
\text {-Traditional classroom; } \\
\text { teacher is female } \\
\text {-permissive problem } \\
\text { solver; but authoritarian } \\
\text { teacher } \\
\text {-dressed in } \\
\text { skirts/dresses }\end{array}$ & $\begin{array}{l}\text { - Power lies in the } \\
\text { classroom authority of } \\
\text { the teacher; repeated line } \\
\text { "something will have to } \\
\text { be done" - said by the } \\
\text { students this time, not by } \\
\text { the teacher as in the last } \\
\text { book } \\
\text {-Aspect of problem- } \\
\text { solving introduced }\end{array}$ & $\begin{array}{l}\text { - Teacher always } \\
\text { addressed as Miss; } \\
\text { Principal portrayed as a } \\
\text { hapless male entertainer } \\
\text {-Focus on the teacher } \\
\text { having more authority in } \\
\text { the classroom and being } \\
\text { more adept than the } \\
\text { principal }\end{array}$ \\
\hline $\begin{array}{l}\text { Teacher } \\
\text { represented as } \\
\text { secondary to } \\
\text { student- } 1985 \\
\text { (male author), } \\
\text { Robert Munsch } \\
\text { Series: } \\
\text { Thomas's } \\
\text { Snowsuit }\end{array}$ & $\begin{array}{l}\text { - Permissive; child- } \\
\text { centred } \\
\text {-Teacher female; (un- } \\
\text { named) short wavy } \\
\text { hair; red trimmed } \\
\text { glasses at the beginning } \\
\text { of the book } \\
\text {-later, messy, spiky } \\
\text { hair, glasses askew } \\
\text {-Stereotype: child has } \\
\text { power, adults are } \\
\text { ineffective }\end{array}$ & $\begin{array}{l}\text {-Teacher and principal } \\
\text { are incompetent in their } \\
\text { control over student } \\
\text {-student always wins } \\
\text {-Child holds power, } \\
\text { adults are ineffective in } \\
\text { authority, and need to get } \\
\text { physical }\end{array}$ & $\begin{array}{l}\text {-Teaching is all about } \\
\text { having power over and } \\
\text { management of the student } \\
\text { - "Thomas, put on that } \\
\text { snowsuit!" (said by } \\
\text { teacher, male principal) } \\
\text { - Satire and humor; } \\
\text { teachers /teaching is a joke }\end{array}$ \\
\hline
\end{tabular}

Cohort One, as above-noted in Table 1, is beneficial in its portrayal of the themes of teacher behaviour, student management in class and the way in which teachers are portrayed in picture books at the time of writing.

The main theme uniting the texts is a view of teacher behaviour coinciding with an authoritarian style of classroom management and personal characteristics. Allard's (1977, 1982) books depicted classroom management style to be authoritarian and stern, suggesting that those who could control children were the best teachers. Munsch (1985) employed satire and irony to humorize direct authoritarian rule, making class management extreme, disrespectful, and definitively not serious. Evidence of satire or dismay toward the career of teaching was prevalent. Behaviour was the focus more than intellect or character. There was also an undercurrent that teachers were not very bright or competent, and principals 
were less so; hence, the profession was not presented in an appealing way. Classroom management was reduced to a metaphor of lion tamer.

Classroom management problems were portrayed as student-driven-and not a product of teacher skill (or lack of skill). Miss Nelson (Allard, 1977) stated that her class was "the worst behaved class in the whole school," and regularly repeated that "something will have to be done" regarding the classroom management of such unruly children. Ironically this phrase is later parroted by the students: about Miss Nelson herself (Allard, 1977).

Classroom management was also closely tied to physical appearance and reinforced the discourse being read. Miss Swamp/Miss Nelson (Allard, 1977), for example, are two alter-egos. The stereotype of the good Miss Nelson (Allard, 1977; 1982), is blonde, kind, has a sense of innocence and well meaning, but is unsuccessful in her class management. The stereotype of the evil Miss Nelson (Allard, 1977; 1982), with black hair and garments, black nail polish, and long black nails is unattractive and authoritative, and successful in her classroom management. The teacher is predominantly portrayed as a witch; a person to be feared in the classroom for harsh presence and making students do work. In the same vein, Munsch (1977), portrayed children also as being rude and disrespectful, while presenting the teacher and principal as being utterly incompetent in solving the problems within the classroom. Could this also awaken a subversive agenda that women, as the first point of behavioural contact, are the ones who cannot cope with the professional workplace, even if the men do appear to be likewise incapable of solving the class management problem? As more women became culturally liberated within society in this cohort of books, perhaps the equality mandate was not as appreciated by these male authors who commented on female ability. Perhaps only the harsh women who governed like traditional male leaders in other social professions were acceptable. In the end, the clever intellect, although left unstated, did go to the problem-solving plans of the blonde Miss Nelson (Allard, 1977; 1982) after all. And, all of the male authors seemed to have a preference for blonde female teachers in their depictions. Our epistemological shudders here appeared in the form of questions: Could this decade of books reflect a social and cultural view that male authors still prefer teachers that look appealing but do not match up in professional status? Is it possible that men and women see problem-solving for behaviours differently? Regardless of the answers to the above questions, classroom management, although evident as a theme in some form, is more in line with a zookeeper managing a zoo than with promoting the value of learning.

\section{Cohort two (1990s).}

This selection continues to trouble the waters regarding the representation of the profession of teaching, and the representation of the character of the teacher in early children's literature.

Two newly emerging themes connect the texts within this cohort, opening the door to a different style of classroom management. Both involve a social context. The individual student becomes more of a focus that the class as a community of learners. Process and progress engaged within experiential teaching and learning is gradually rising as a major constructivist pedagogy.

More attention is given to the individuality of the 'subject specialist' teacher, with a particular emphasis on the subject disciplines of math and science. A nostalgic or heroic

Language and Literacy 
view of the teacher as a personal stereotype who in some ways endures a trial or loss in relational aspects becomes more common. Male teachers become represented as being more 'professional' in illustration and in manner. These books were written at a time in culture when men were being encouraged to enter the teaching profession. This may attribute to the fact that men were represented to be more competent than their stereotypical, or caricatured female counterparts in illustration and in tone.

Table 2

Cohort 2: Professional Change, Social Change, \& Possible Significance

\begin{tabular}{|c|c|c|c|}
\hline Character* & $\begin{array}{l}\text { Professional change } \\
\text { (Illustration and } \\
\text { valued disposition and } \\
\text { pedagogy) }\end{array}$ & $\begin{array}{l}\text { Social change } \\
\text { (Class management and } \\
\text { teaching focus) }\end{array}$ & $\begin{array}{l}\text { Possible significance } \\
\text { (Representation of } \\
\text { power) }\end{array}$ \\
\hline $\begin{array}{l}\text { Ms. Frizzle- } \\
1990 \\
\text { (female author) } \\
\text { Magic } \\
\text { Schoolbus } \\
\text { Series: }\end{array}$ & $\begin{array}{l}\text {-Experiential, } \\
\text { constructivist \& } \\
\text { project-based pedagogy } \\
\text {-Learning in non- } \\
\text { traditional settings } \\
\text {-Little class } \\
\text { management is overt or } \\
\text { directive unless in } \\
\text { danger; facilitated or } \\
\text { arranged learning }\end{array}$ & $\begin{array}{l}\text {-Teaches science } \\
\text { (formerly a male- } \\
\text { dominated subject) } \\
\text {-Embraces danger } \\
\text { Emphasis on STEAM to } \\
\text { draw more female } \\
\text { teachers into science, } \\
\text { technology, } \\
\text { environmental, art and } \\
\text { math subject teaching }\end{array}$ & $\begin{array}{l}\text {-Change in how genders } \\
\text { are depicted as being good } \\
\text { teachers; more diversity. } \\
\text {-Change to see students as } \\
\text { more individual learners } \\
\text { than as a class of learners. }\end{array}$ \\
\hline $\begin{array}{l}\text { Mr. Falker-1998 } \\
\text { (female author), } \\
\text { Mr. Blueberry- } \\
1991 \text { (male } \\
\text { author), Mr. } \\
\text { Slinger } 1996 \\
\text { (male author) }\end{array}$ & $\begin{array}{l}\text {-Use unconventional } \\
\text { methods to unlock } \\
\text { learning } \\
\text {-Student centered; } \\
\text { Work with individual } \\
\text { students across themes } \\
\text { of disability, an interest } \\
\text { in science, and an area } \\
\text { of social conflict }\end{array}$ & $\begin{array}{l}\text {-Male teachers in an } \\
\text { elementary classroom } \\
\text { showing relational rather } \\
\text { than solely } \\
\text { administrative traits } \\
\text {-Mr. Slinger introduces } \\
\text { the new neology of slang } \\
\text { into children's picture } \\
\text { books and classroom } \\
\text { conversations }\end{array}$ & $\begin{array}{l}\text {-All male teachers exhibit } \\
\text { clear class management, } \\
\text { but also tender traits } \\
\text { toward the learners } \\
\text {-Mr. Blueberry and Thank } \\
\text { you, Mr. Falker are written } \\
\text { by former students of real } \\
\text { teachers in memoir style, } \\
\text { denoting personal life } \\
\text { experience that affects the } \\
\text { future of a student. }\end{array}$ \\
\hline $\begin{array}{l}\text { Mrs. Neal- } 1992 \\
\text { (female author) }\end{array}$ & $\begin{array}{l}\text {-Mothers having a baby } \\
\text { can be teachers too } \\
\text {-Uses cross-curriculum } \\
\text { to tie in to her future } \\
\text { departure, using science } \\
\text { (life cycle) and social } \\
\text { studies (designing a } \\
\text { baby's room) }\end{array}$ & $\begin{array}{l}\text {-Married women could } \\
\text { have careers and be } \\
\text { moms too } \\
\text {-Will return and leave } \\
\text { child in child care }\end{array}$ & $\begin{array}{l}\text {-Introduces a maternity } \\
\text { leave as being legitimate } \\
\text { in a career } \\
\text {-Style of teacher } \\
\text { authenticity is the } \\
\text { teacher's subversive } \\
\text { classroom management } \\
\text { style; not overt }\end{array}$ \\
\hline
\end{tabular}




\begin{tabular}{|c|c|c|c|}
\hline $\begin{array}{l}\text { Miss Malarkey - } \\
1998 \\
\text { (female author) }\end{array}$ & $\begin{array}{l}\text {-Represents the driven } \\
\text { teacher, comes in when } \\
\text { ill, always under stress, } \\
\text { exhausted } \\
\text {-Classroom out of } \\
\text { control; students take } \\
\text { over to restore order } \\
\text { and care for the teacher }\end{array}$ & $\begin{array}{l}\text {-Emphasizes the stress of } \\
\text { teaching } \\
\text {-Parody - all names of } \\
\text { teachers show weakness } \\
\text { or unsuitability to } \\
\text { professional life }\end{array}$ & $\begin{array}{l}\text {-Portrays teaching as a } \\
\text { very serious and stressful } \\
\text { job } \\
\text {-Leadership and care role } \\
\text { exchanged with the } \\
\text { student/teacher role }\end{array}$ \\
\hline $\begin{array}{l}\text { Mrs. K - } 1999 \\
\text { (female author) }\end{array}$ & $\begin{array}{l}\text {-Portrays a teacher with } \\
\text { cancer }\end{array}$ & $\begin{array}{l}\text {-Contemporary teaching } \\
\text { style; calls students } \\
\text { friends; blur of authority } \\
\text { between teacher and } \\
\text { student }\end{array}$ & $\begin{array}{l}\text { Emphasizes the relational } \\
\text { aspects of teaching as } \\
\text { being paramount }\end{array}$ \\
\hline
\end{tabular}

*sample of texts

In this cohort of books, the relational side of teaching, the result of teaching, and the struggle of teaching make an entrance. We discover new teacher typologies: the teacher as friend, the teacher as scientist, the teacher as compassionate facilitator and the driven teacher.

Although the themes of authority from the first cohort still linger, the depth of attention on class management is becoming more individualistic on the part of the teacher, and more interchangeable, as the teacher and student are socially becoming more equal in having authority in the classroom. How significant then, is classroom management? If classroom management is not deemed a focus, does it cease to exist?

In summary, out of the 14 books in this cohort, three male, and eleven female teachers were represented. Individual learning, role modelling, learning styles, science and introduction to a family or social life for teachers as well as a professional life was an overarching theme. Introduction of special needs in this cohort (dyslexia) portrayed male teachers as being more professional and geared to helping students learn. Some female teachers appear to be more caricatured and stereotypical. All authors except three were female.

\section{Cohort three (2000-2005).}

Books in this cohort (see Table 3) depict themes of comical characters, science, art, teachers in turmoil, and a change in the portrayal of the teacher from that of an adult authority figure, to that of friend or fiend. These books mirror many similarities noted in cohorts one and two in regard to classroom management and teacher dispositions (especially the negative ones). The majority of the books deal with teacher dispositions, representing formerly visited aspects that make teachers more extreme. The reader re-visits an alien teacher who is "the toughest teacher in town" (Passen, 2000). Her classroom is managed by militaristic rule and fear of punishment, presenting a stereotype of a female teacher who manifests a robot-like personality reminiscent of a superhero: she can be Jekyll or Hyde. Wheatley and Ottley (2000), portray similar dispositions in an elderly male teacher who is menacing and yells, ruling children by fear. When angry, he destroys 
property. Although dressed in a suit and tie, his hands are portrayed as claws. He rules with words such as "what's wrong with you" and "[the teacher] went ballistic; he went off his brain", showing an unstable mind and disposition for teaching. Being in control is more important than student learning. The act of classroom management is manipulative, violent, unrealistic and bizarre. Hallinanx (2000) portrays the 'perfect teacher' through the eyes of a student who is writing a poetic ode about her as being blonde, wearing glasses and dressing so that everything matches. She is a friend, perfect in certain teacher dispositions, such as greeting students, singing and covering subject matter perfectly. In contrast, another book in the Miss Malarkey series such as Testing Miss Malarkey (Finchler \& O'Malley, 2000), deals with teacher anxiety and standardized tests. Miss Malarkey (Finchler \& O'Malley, 2000) is also blonde with long hair and has dark circles under her eyes. She is 'anxious, stressed, tired and weird' as well as being empathetic to students. Everything focuses on 'the test'. Her direct instruction was considered to be effective because the school won as county champions and everyone got a prize. Function overrides essence. The teacher is a prisoner in a prison of students cramming for this test. None of the above teachers represent an average, balanced human as a teacher.

Table 3

Cohort 3: Professional Change, Social Change, \& Possible Significance

\begin{tabular}{|c|c|c|c|}
\hline Character* & $\begin{array}{l}\text { Professional change } \\
\text { (Illustration and } \\
\text { valued disposition and } \\
\text { pedagogy) }\end{array}$ & $\begin{array}{l}\text { Social change } \\
\text { (Class management and } \\
\text { teaching focus) }\end{array}$ & $\begin{array}{l}\text { Possible significance } \\
\text { (Representation of } \\
\text { power) }\end{array}$ \\
\hline $\begin{array}{l}\text { Arthur's } \\
\text { Teacher }-2000 \\
\text { (male author) }\end{array}$ & $\begin{array}{l}\text { - Jeans, t-shirt, needs } \\
\text { help in his personal life; } \\
\text { stays with many } \\
\text { families. } \\
\text {-Nicknamed Mr. } \\
\text { Ratbite; depicts divide } \\
\text { between personal and } \\
\text { professional life } \\
\text {-Desire to be liked by } \\
\text { students } \\
\text {-More about teacher's } \\
\text { personal life than } \\
\text { teaching role }\end{array}$ & $\begin{array}{l}\text { - Math and science } \\
\text { teacher (subjects thought } \\
\text { to be of value) } \\
\text { - Entertains students with } \\
\text { magic tricks; student } \\
\text { centred, is fun } \\
\text { - Teacher presented as } \\
\text { someone in need }\end{array}$ & $\begin{array}{l}\text {-Change in how genders } \\
\text { are depicted as being good } \\
\text { teachers } \\
\text {-more diversity in personal } \\
\text { aspect of the teacher. } \\
\text {-Profession perhaps } \\
\text { appears to attract needy } \\
\text { teachers }\end{array}$ \\
\hline $\begin{array}{l}\text { My Teacher is } \\
\text { my Friend - } \\
2000 \\
\text { (male author) }\end{array}$ & $\begin{array}{l}\text { - Female teacher, } \\
\text { blonde feathered hair, } \\
\text { glasses, plaid skirt, } \\
\text { green sweater, } \\
\text { matching shoes, smiley } \\
\text { face button }\end{array}$ & $\begin{array}{l}\text {-Focus is on the 'perfect' } \\
\text { teacher in appearance } \\
\text { and dispositon } \\
\text {-No classroom } \\
\text { management or } \\
\text { pedagogy noted; all } \\
\text { about the appearance and }\end{array}$ & $\begin{array}{l}\text {-Appearance is seen as } \\
\text { more significant than skill } \\
\text { in teaching } \\
\text {-Somewhat of a care taker } \\
\text { role; portrays a female } \\
\text { teacher as a perfect }\end{array}$ \\
\hline
\end{tabular}




\begin{tabular}{|c|c|c|c|}
\hline & $\begin{array}{l}\text {-Represents the perfect } \\
\text { teacher; seen as } \\
\text { student's friend, greets } \\
\text { students, sings, caring, } \\
\text { competent, done in } \\
\text { poetic rhyme, lilty. }\end{array}$ & $\begin{array}{l}\text { disposition of the teacher } \\
\text { as being appealing to } \\
\text { students as she entertains } \\
\text { and nurtures them }\end{array}$ & $\begin{array}{l}\text { mom/care giver but not as } \\
\text { much as a teacher }\end{array}$ \\
\hline $\begin{array}{l}\text { Miss Malarkey- } \\
2000 \\
\text { (female author) } \\
\text { Miss Malarkey } \\
\text { Series: Testing } \\
\text { Miss Malarkey }\end{array}$ & $\begin{array}{l}\text {-Focus is on } \\
\text { standardized tests } \\
\text {-Female teacher, long } \\
\text { blonde hair, wearing } \\
\text { skirts, circles under } \\
\text { eyes, biting nails }\end{array}$ & $\begin{array}{l}\text { - Teacher as prisoner to } \\
\text { beaurocracy; teaching to } \\
\text { the test } \\
\text {-Direct instruction } \\
\text {-Class management is } \\
\text { secondary to acing the } \\
\text { test }\end{array}$ & $\begin{array}{l}\text {-Portrays teaching as a } \\
\text { stressful profession } \\
\text {-Winning the test trumps } \\
\text { over learning } \\
\text {-Teaching seen as satirical } \\
\text { fun to the detriment of the } \\
\text { teacher }\end{array}$ \\
\hline $\begin{array}{l}\text { Piano teacher } \\
\text { mom vs } \\
\text { classroom } \\
\text { teacher - } 2001 \\
\text { (female author) }\end{array}$ & $\begin{array}{l}\text {-Represents a piano } \\
\text { teacher mom and a } \\
\text { classroom teacher in } \\
\text { contrast and } \\
\text { comparison } \\
\text { - Attire: female teacher } \\
\text { wears hair in a bun, } \\
\text { black dress, string of } \\
\text { pearls, while piano } \\
\text { teacher mother wears } \\
\text { fancy hairdo, big } \\
\text { earrings, strange shoes }\end{array}$ & $\begin{array}{l}\text { - School teacher is strict, } \\
\text { harsh and condescending } \\
\text { and mom is graceful and } \\
\text { elegant } \\
\text { - Contasts young girl's } \\
\text { mom as piano teacher } \\
\text { (home) and school } \\
\text { teacher in both teaching } \\
\text { style and popularity }\end{array}$ & $\begin{array}{l}\text { - School teacher - students } \\
\text { obedient but not happy; } \\
\text { piano teacher popular with } \\
\text { parents and students } \\
\text { - Perhaps suggests home } \\
\text { schooling as the preferable } \\
\text { teacher choice and that } \\
\text { teachers should be more } \\
\text { nurturing }\end{array}$ \\
\hline $\begin{array}{l}\text { Perfect man- } \\
2004 \\
\text { (male author) }\end{array}$ & $\begin{array}{l}\text { - Male teacher: middle } \\
\text { aged, shirt, tie, vee- } \\
\text { neck sweater, brown } \\
\text { slacks and shoes, } \\
\text { thinning hair, round } \\
\text { stomach, middle aged } \\
\text { man }\end{array}$ & $\begin{array}{l}\text { - Perceived by student as } \\
\text { being Perfect Man, } \\
\text { superhero in comic; } \\
\text { patient, encouraging } \\
\text { student to be a writer; } \\
\text { never broke chalk, never } \\
\text { got sick or lost temper } \\
\text {-Effective: writer/student } \\
\text { becomes writer and } \\
\text { teacher becomes biggest } \\
\text { fan }\end{array}$ & $\begin{array}{l}\text { - Male teachers do not } \\
\text { need to have any } \\
\text { appearance factor, and are } \\
\text { successful by being } \\
\text { effective in student } \\
\text { support } \\
\text { - Male teachers may be } \\
\text { taken more seriously }\end{array}$ \\
\hline $\begin{array}{l}\text { Male PE teacher } \\
\text { - } 2004 \\
\text { (male author) }\end{array}$ & $\begin{array}{l}\text { - Male teacher: ball cap, } \\
\text { running shoes, whistle, } \\
\text { t-shirt, athletic pants - } \\
\text { gym teacher } \\
\text { sports day, "Just try } \\
\text { your best" }\end{array}$ & $\begin{array}{l}\text {-Contemporary teaching } \\
\text { style; blur of authority } \\
\text { between teacher and } \\
\text { student; Role reversal - } \\
\text { when teacher cannot do } \\
\text { something student says } \\
\text { try your best }\end{array}$ & $\begin{array}{l}\text { Emphasizes the relational } \\
\text { aspects of teaching as } \\
\text { being paramount } \\
\text { in field day environment. } \\
\text {-If you can teach sport, } \\
\text { you can teach anything }\end{array}$ \\
\hline
\end{tabular}

*sample of texts 
Books that portrayed teachers as being extreme, perfect, dangerous, stressed, or driven depicted them more as professional caricatures or stereotypes than as real humans in the profession of teaching. The focus here was on direct teaching to acquire a result. In this cohort, representations of teachers include being elderly, nurturing, interactive with, but unequal to parents. Paraskevas (2001), presented the teacher as silver-haired, in a blue dress with a pearl necklace and glasses; a teacher who "never forgets a name". However, in this book, the teacher receives one page on her appearance followed by poems from the students that rhyme, are off-putting at times, and are represented as humour at the student's expense. Class management includes vindictiveness, satire, irony, and negativity. For example, the teacher was not what she appears to be. Another book uses descriptors such as "teachers like to help students one at a time" as a purveyor of the knowledge economy; a picture book acting like a Sears catalogue of days gone by for the profession. The book contains pictures of professionally dressed teachers of both genders and provides facts of information about the teaching profession. It is 'occupation' focused, presented in thirdperson narration. The reader is a neutral outsider. Here the student is seen as the consumer of information about the profession of teaching.

Many depictions of teachers are positive, lauding exceptional teaching skills. Other books demonstrate negative views of teachers, often depicted through their appearance or temperament (e.g., Paraskevas, 2001; Passen, 2000; Reynolds, 2001). In one instance, gardening is used as a metaphor for the nurturing teacher. The teacher believes children will flourish if lovingly tended as she is doing with the plants, linking to science in the environment (Pattou, 2001). None of the book takes place in school, but in the garden at the teacher's home. Experiential environmental learning is key. Reynolds (2001) contrasts a teacher in the classroom (black dress, hair in a bun, strict) and the parent of a young girl new to the school who is a piano teacher. The teacher at school is harsh and condescending to the new student, while the parent is elegant and graceful. Students of the teacher are obedient but not happy, while parents of the piano teacher happily brought their children for teaching. The book compares the two dispositions for teaching music, and more importantly, the intent and reasons for doing so. In Teachers, (Flanagan, 2001), a book written to present the career of teaching, teachers are presented as being well trained, skilled and well organized. However, they are not presented as being well educated; "Teachers can help children and adults learn. All teachers graduated from college." It is a very dry and dated portrayal. As with other books in this mode, the presentation of teaching being a trade, not a profession, is assumed by the treatment of the topic. Teyssedre (2001), reduces the professional and representative role of the teacher to a caricature of cartoon figures in anthropomorphical representation. Joseph is a monkey, and the teacher is another creature in the zoo. These books portray teachers as being insufficient either in the professional aspects of teaching or in relational aspects within the teaching-learning process, and therefore, perhaps becoming non-essential or non-preferable to the teaching from parents or alternative sources.

This cohort also shows a rise in sarcastic representations of teachers. Johnson (2002) represents teachers as deceptive (i.e., faking sick days); careless (i.e., leaving the incorrect lesson plan for a sick day); being represented as a lion tamer (another managing the zoo metaphor); and summarizing teaching by saying "anybody who can train lions could handle kids." The book portrays teaching as being worthy when it is fun. Anyone 
can teach. The everyday teacher is loved by the students, but does not value academic learning. Activities done were extreme and dangerous, highly exaggerated, and unrealistic.

Academics appear to be unwanted, and fun is desired. And so, it appears, is nonsense. In the book Wood (2002), teachers are anthropomorphically depicted in cartoon format as dinosaurs. Irony is used in their directive style of teaching, and students question the processes and rules in the classroom. Teachers are mis-portrayed for what they can't do; "they can't use the hall pass to go to the bathroom," rather than, "teachers do not need a hall pass to go to the bathroom." This portrayed the teacher as being inferior to the student, "a teacher can't spell CAT," from a student perspective.

Danneberg (2003) is penned from a student perspective, with no voice on the part of the teacher. The teacher portrayed in the text is loved by students for field trips, is kind, and holds their hands. In being assessed by the principal, the teacher is presented as an equal, not as an authority. The teacher wants to be liked and gets a congratulations party at the end of her assessment.

To conclude this cohort, the included books portrayed a male middle-aged teacher suspected to be a superhero, a male coach, a female pioneer teacher who keeps children safe during a blizzard, and a disheveled teacher on the first day of grade school. These portrayals also show role reversals or mediated views of the teacher/student relationship. The superhero male teacher is described as the perfect man. He "never broke chalk, never got sick, was the fastest marker and never lost his temper. He was everywhere at once." $\mathrm{He}$ is a hero to the student in the book for being nurturing, gently challenging and encouraging, and the student becomes a writer due to his care and instructive guidance. The teacher then became the writer/student's greatest fan.

A male coach had a motto: "Try your best." The teacher was effective in getting the students to try things in sport and in encouraging them to succeed. However, a role reversal occurred when the teacher says he can't do something, and the students respond with his phrase 'just try your best'. The satirical exploration of life in the primary classroom in this cohort was summarized in the portrayal of a teacher attired in a long blue skirt, with long red hair, who progresses from being neat to dishevelled, perplexed, overwhelmed, bewildered. In another context, a teacher was presented in parody as a zoo keeper, putting up with whatever creatures children gift her with in the classroom. The teacher was at the mercy of the class. Students hold the power, and the teacher is in some ways treated as the victim of the class; even by the bureaucracy that serves her.

It is interesting to note that many teachers are elderly. The male teachers frequently seem to not be in any position where they are dealing with challenge or misbehaviour on the part of the class. Classroom management, overall, was treated as a source of ridicule, satire, or is best left to the students. Use of irony, sarcasm, and a mix of role reversal between student and teacher became apparent. Emphasis appears to have increased regarding being liked, being fun, being fair. Less emphasis is on learning than experiencing. Teaching as a profession was mostly, simply a mockery. Teachers were represented as sixteen female, four male, two cartoon depictions and two professional stereotypes. In this selection, thirteen authors were female and nine were male. Two professional books, which were geared to being advertising manuals for teaching as a profession, do not appear in the results.

Twenty-two samples are represented in this cohort. Teachers were represented as 16 female, 4 male, ( 2 cartoon depictions), and 2 professional examples. More emphasis 
was on the permissive classroom. Use of irony, sarcasm, and gender are notable. Many teachers are stereotyped, caricatures, compared to super-heroes. Emphasis appears to have increased regarding being liked, being fun, being fair. Less emphasis is on learning than experiencing. In this section, 9 of the authors were male. General themes involved gender representation, alignment (or not) with professional requirements, stereotypes, and teaching as having fun.

\section{Summary}

This study reveals a perspective of what teachers were perceived to be and to do in picture books from the 1970s to the early 2000s, as included in the Picture books from the A-Zoo $7^{\text {th }}$ Edition (2005). It is not without limitations, as a picture book is also designed to entertain, and has license with accuracy in that regard. Consumerism within the boundaries of creating a book that will sell, often re-shapes the reason behind the text, and the liberty taken with story may be more amusing than the reality of the profession of teaching. However, such portrayals are not innocent, and do lead to some misconception about the professionalism of the teaching career. What is inferred is as significant as what is stated. The scope of themes raised in this study (professional change, social change, teaching style, gender, teacher behaviour, professional appearance, classroom management, character of the teacher, experiential learning pedagogy, individualism in the classroom, community, empathy, and more) display the canopy of difficulty buried in teacher/student/institutional life. In each theme, Charteris's heuristic of epistemological shudders provoked "aha" and "oh no" conjectures as to how themes over time affect schooling and its outcomes. What was not being said spoke as loudly as what was being said.

In the majority of the books in this study, classroom management was not overtly or deliberately identified. In many ways, this study is as much a view of students as of teachers. Students progressively become portrayed as being more of a directing voice for, or caregiver to, the teacher. There is burgeoning student input into what is to be taught, the way it should be taught, and who should actually teach it. Stereotypes of teachers were presented as being more insignificant and depressing, even if they are more fun loving, better liked, and less directive or demanding. They were often stressed out. Male and female teachers were balanced in portrayal as 'best teachers.' Although the books frequently divulged binary opposites when read independently, 'the teacher' collectively is presented in ways that students would see as being more inclusive. There is an underlying pattern that the undesirable portrayal of teachers is represented by teachers who are either elderly or female. Male principals are still ridiculed, but there are no female principals noted. This may represent a cultural distaste for women in authority as it relates to power in educational systems, or to past experience with a principal in the life of the author. Stories where teachers were depicted as anthropomorphic caricatures were less professional in representation and often included mockery of some serious aspects of professional teaching.

Across cohorts, teachers were also given (and in retrospect also forgiven) their eccentricities or unprofessional language and slang. Teachers were less required to act as if they were educated. Representation of a stereotype was beginning to overshadow the key discourse of classroom management and of learning. This shift, in itself, presents the years of books within the study as being representative of a time of educational shift and change. 
Gender representation posed a consideration. Could it be presumed that with the majority of the authors being female, that teachers should be socially deemed to be female? Would this represent teaching as a profession as being inferior in the eyes of males? Or would the presence of male teachers emerging from the pen of female authors say otherwise? Are any of the authors teachers (insiders)? The first cohort had male writers who depicted teachers as being female. The second cohort had male writers, but few presented books with male teachers. Overall, the study as a whole had thirteen of the thirtynine, one third, of authors being male, but only seven represented male teachers as key figures. However, these picture book selections are firmly part of their geopolitical context and cohort. Looking ahead, more recent cohorts would no doubt reflect societal change and trends in gender expectations, gender expression, and much more.

In conclusion, it is possible from this study to present teaching in the elementary grades as being seen as a 'lesser profession'. Females were often portrayed as blondehaired women who cannot either handle the stress of the job or the behaviour of the class as well as their male counterparts. The attire of the teachers showed more professional dress on the portrayal of male teachers in the literature. The female teachers were shown to be encountering the difficulty of teaching more than their male counterparts in picture books. These books, overall, can be seen to favour a humorous portrayal of a serious profession: but not an accurate one.

At one time, it appeared that teachers were valued for having a sound character, at another, merely for having a likeable method of engagement. They also had a reason for teaching, a philosophy of education, which was not evident anywhere in their portrayal. The teacher was portrayed as more of a zookeeper in picture books than a moral mentor, guide or model of how to live a life when school ends. The time, thought, management, and care coupled with emotional intelligence to be a capable teacher is not frequently evident, nor is the respectful consideration of a demanding occupation. The authors suggest that the implications from this study are significant for classroom practice and could be studied in a data set from 2005 onward to see if this trend wanes or increases in picture book representation. For future research, a study of picture books beyond 2005 would be worthy of attention and provide data for comparison.

\section{References}

Charteris, J. (2014). Epistemological shudders as productive aporia: A heuristic for transformative teacher learning. International Journal of Qualitative Research, 13(1)104-121. doi: 10.1177/160940691401300102

Christen, R. S. (2001). 'An absolute monarch in his school' images of teacher authority in the seventeenth-century English Character literature. History of Education, 30(4), 321-338.

Cummins, A. (2009). An honour to be a teacher: Antebellum literary depictions of school women. Women's Studies, 38(7), 799-817.

De Witt, A. (2013). Parental role portrayals in twentieth century children's picture books: More egalitarian or ongoing stereotyping? Sex Roles, 69(1-2), 89-106.

Dockett, S., Perry, B., \& Whitton, D. (2010). What will my teacher be like? Picture storybooks about starting school. Australasian Journal of Early Childhood, 
35(3), 33-41.

Feathers, K. M. \& Arya, P. (2012). The role of illustrations during children's reading. Journal of Children's Literature, 38(1), 36-42.

Hansen, A. (2009). Researching 'teachers in the news': The portrayal of teachers in the British National and regional press. Education, 37(4), 335-347.

Hollis-Sawyer, L., and Cuevas, L. (2013). Mirror, mirror on the wall: Ageist and sexist double jeopardy portrayals in children's picture books. Educational Gerentology, 39(12), 902-914.

Krippendorff, K. (1989). Content analysis. In E. Barnouw et al. (Ed.) International encyclopedia of communication (pp. 403-407). New York: Oxford University Press.

Lima, C. (2006). A to zoo: Subject access to children's picture books ( $7^{\text {th }}$ ed.). Wesport, CT: Libraries Unlimited.

Mockler, N. (2004, November/December). Architects, travel agents and bus drivers: Images of teacher professional identity in public discourse. Paper presented at the annual Australian Association for Educational Research Annual conference, Melbourne, Australia.

Muchmore, J.A. (2012). From Laura Ingalls to Wing Biddlebaum: A survey of teacher identities in works of literature. Issues in Teacher Education, 21(1), 5-20. Retrieved from https://files.eric.ed.gov/fulltext/EJ986813.pdf

Muchmore, J. A. \& Sayre, E. G. (2009). Literary Portrayals of Teachers. In, E. R. Provenzo Jr (Ed.), Encyclopedia of the Social and Cultural Foundations of Education (pp. 792-795). Thousand Oaks, CA: Sage Publication.

Phillips, E. \& Sturm, B.W. (2013). Do picture books about starting kindergarten portray the kindergarten experience in developmentally appropriate ways? Early Childhood Education Journal, 41(6), 465-475.

Sandefur, S.J. \& Moore, L. (2004). The 'nuts and dolts' of teacher images in children's picture storybooks: A content analysis. Education, 125(1), 41-53.

Townsend, J. S. \& Ryan, P. A. (2012). Media narratives and possibilities for teacher's embodied concepts of self. Journal of Media Literacy Education, 4(2), 149-158.

Trousdale, A.M. (1992). Why is this teacher smiling? Portrayals of teachers in picture books for young children. Feminist Teacher, 6(3), 25-31.

\section{Children's Picture Books}

Allard, H. (1977). Miss Nelson is missing. Boston, MA: Houghton Mifflin Harcourt. Allard, H. (1982). Miss Nelson is back. Boston, MA: Houghton Mifflin Harcourt. Borden, L. (1999). Good luck Mrs. K! New York, NY: Margaret K. McElderry. Brenner, E. (2004). On the first day of grade school. Toronto, ON: Harper Collins Publishing.

Brown, M. (2000). Arthur's teacher moves in. Boston, MA: Little Brown and Company. Bunting, E. (1992). Our teacher's having a baby. New York, NY: Houghton Mifflin. Calmenson, S., \& Roche, D. (1998). The teeny tiny teacher. New York, NY: Scholastic. Cole, J., \& Degen, B. (1990). The magic school bus Lost in the solar system. New York, NY: Scholastic.

Cole, J., \& Degen, B. (1992). The magic schoolbus on the ocean floor. New York, 
NY: Scholastic.

Cole, J., \& Degen, B. (1996). The magic schoolbus inside a beehive. New York, NY:

Scholastic.

Danneberg, J. (2000). First day jitters. Watertown, MA: Charlesbridge.

Danneberg, J. (2003). First year letters. Watertown: Charlesbridge, Whispering Coyote.

Figley, M. (2004). The schoolchildren's blizzard. Minneapolis, MN: Learner Publishing Group.

Finchler, J. (1998). Miss Malarkey won't be in today. New York: Walker Children's Books.

Finchler, J., \& O'Malley, K. (2000). Testing Miss Malarkey. New York: Walker \& $\mathrm{C}$ Company.

Finchler, J. (2002). You're a good sport Miss Malarkey. New York: Walker Publishing Company.

Flanagan, A. (2001). Teachers. Chicago: Compass Point Books

Garland, M. (2003). Miss Smith's incredible story book. Boston, MA: Dutton Juvenile.

Greene, C. (1997). Teachers help us learn. New York: Child's World.

Hallinan, P. K. (2000). My teacher's my friend. Nashville: Ideals Children's Books.

Henkes, K. (1996). Lilly's purple plastic purse. New York, NY: Greenwillow Books.

Houston, G. (1992). My great aunt Arizona. New York, NY: Balzar and Bray.

James, S. (1991). Dear Mr. Blueberry. New York, NY: M. K. McElderry Books.

Johnson, D. (2002). Substitute teacher plans. New York, New York: Henry Holt and Company.

Liebman, D. (2001). I want to be a teacher. Richmond Hill, ON: Firefly Books.

Flanagan, A. (2001). Teachers (community workers). Mankato, MN: Compass Point Books.

Munsch, R. (1985). Thomas's snowsuit. Toronto, ON: Annick Press.

McKissack, R. (2004). Try your best. San Diego, CA: Green Light Readers.

Paraskevas, B. (2001). Gracie Graves \& the kids from room 402. San Diego, CA: Harcourt.

Passen, L. (2000). The attack of the 50-foot teacher. New York, NY: Henry Holt and Company.

Passen, L. (2002). The incredible shrinking teacher. New York, NY: Henry Holt and Company.

Pattou, E. (2001). Mrs. Spitzer's garden. Orlando, FL: Harcourt.

Polacco, P. (1998). Thank you, Mr. Falker. New York, NY: Philomel Books.

Priceman, M. (1999). Emeline at the circus. New York, NY: Knopf Books for Young Readers.

Reynolds, M. (2001). The magnificent piano recital. Victoria, BC: Orca Publishers.

Teyssedre, F. (2001). Joseph wants to read. Boston, MA: Dutton Children's Books.

Wheatley, N., \& Ottley, M. (2000). Luke's way of looking. Sydney, Australia: Hodder Children's Books Australia.

Wilson, T. (2004). Perfect man. Victoria, BC: Orca.

Wood, D. (2002). What teachers can't do. New York, NY: Simon \& Schuster Children's Publishing.

Author Biography

Language and Literacy

Volume 21, Issue 4, 2019

Page 19 
Dr. Christina Belcher is Professor and Chair of the Department of Education at Redeemer University College, Ancaster, Ontario, Canada. She has been teaching in Higher Education for over 20 years. Her research interests include worldview, higher education, children's literature, identity, inclusion, and literacy.

Dr. Kimberly Maich is an associate professor in the faculty of education at Memorial University. She is a special education specialist, board-certified behaviour analyst (doctoral), and registered psychologist (provisional). She enjoys teaching, research, and service work in inclusive education; primarily, autism spectrum disorder.

Monte Hardy is a Ph.D. student in the Faculty of Child and Youth Studies at Brock University. He has spent twenty-five years as a professional in the field of Deaf children and youth and their families both in government and the non-profit sector. He enjoys supporting non-profit agencies through organizational transformation, supporting undergraduates in their education, and working with Deaf children, youth and adults in enhancing accessibility. 